\title{
IMPLIKASI DOKTRIN KESELAMATAN YANG BENAR DALAM KEHIDUPAN
}

\author{
Philip Suciadi Chia ${ }^{1)}$ Juanda ${ }^{2)}$ \\ 1) Southern Baptist Theological Seminary - Kentucky USA \\ E-mail: : pchia275@students.sbts.edu \\ 2) Sekolah Tinggi Teologi Injili Indonesia - Surabaya \\ E-mail: juanda@sttii-surabaya.ac.id
}

\begin{abstract}
The doctrine of salvation will have implications in the life of the believer. The implications are not only concerning each individual believer but also fellow believers.

The doctrine of salvation should make a person have a biblical practical life. Not only that, the Biblical concept of salvation will also help lead every believer into the world of evangelism and have a relationship between unbelievers that is in harmony with Bible truth.
\end{abstract}

Keywords: Salvation, Bible, Practical Life

\begin{abstract}
Abstrak
Ajaran keselamatan yang benar akan ada implikasinya di dalam kehidupan orang percaya. Implikasi tersebut bukan hanya berkenaan dengan masing-masing pribadi orang percaya itu sendiri tetapi juga sesama orang percaya. Ajaran tentang keselamatan yang benar, seharusnya membuat seseorang memiliki kehidupan praktis yang Alkitabiah. Tidak hanya itu, konsep keselamatan yang Alkitabiah juga akan membantu mengarahkan setiap orang percaya ke dalam dunia penginjilan serta memiliki hubungan antar orang yang tidak percaya yang selaras dengan kebenaran Alkitab.
\end{abstract}

Kata Kunci: Keselamatan. Alkitab, Kehidupan Praktis

\section{PENDAHULUAN}

Manusia tidak dapat melepaskan diri dari dosa dan tidak ada seorang pun yang mencari Allah. Akan tetapi, keselamatan ini juga merupakan sebuah wahyu dari kebaikan dan kasih Allah. ${ }^{1}$ Pada mulanya Allah memperingatkan manusia dari

\footnotetext{
${ }^{1}$ Louis Berkof, Doktrin Keselamatan (Jakarta:
} Lembaga Reformed Injili Indonesia, 1997), 112. kehancuran diri, menunda pelaksanaan keputusan hukuman mati dan memberkati mereka dengan tawaran keselamatan di dalam Yesus Kristus. ${ }^{2}$

Tidak ada keraguan lagi bahwa tawaran yang penuh kemurahan ini 
sebenarnya bukan berkat dan bukan juga kutukan bagi orang berdosa seperti dianggap oleh sebagian orang. Tawaran ini dengan jelas mengungkapkan belas kasih Allah kepada ciptaan dan semuanya itu (Mzm. 81:13; Ams. 1:24; Yeh. 18:23, 32; 33:11; Am. 8:11; Mat.11:20-24; 23:37). 1 Petrus 1:13-20 juga mengajarkan tentang sikap yang diharapkan sebagai anak-anak Tuhan berkenaan dengan karya Kristus yang besar, yang telah membangkitkan orang percaya dari antara orang mati dan yang memberikan pengharapan dan kekuatan baru. Tidak hanya itu, bahkan melalui kematian Kristus itu telah memberikan orang percaya keselamatan. Dampaknya ialah manusia yang diselamatkan memiliki kehidupan yang baru karena telah diubahkan menjadi manusia baru. ${ }^{3}$

Betapa kita bersyukur atas semua karya Tuhan yang dilimpahkan kepada kita. Oleh karena itu, rasa syukur harus menjadi bagian kehidupan dari orang-orang yang sudah diselamatkan. Memuji Tuhan senantiasa karena kebaikan dan kasih-Nya di dalam menanggung semua kelemahan dan kebodohan orang berdosa.

Dalam karya keselamatan orang percaya juga berhubungan dengan kesucian Allah sendiri yang dengan jelas menentang akan

${ }^{3}$ Ibid., 113.

${ }^{4}$ Ibid., 114. semua bentuk dosa. Dengan dirinya sendiri, manusia tidak akan dapat untuk memperoleh keselamatan-Nya sendiri.

Roma 3:10 mengatakan bahwa semua manusia, tidak ada terkecuali, tidak ada yang benar. ${ }^{4}$ Namun dengan kasih-Nya yang diimbangi dengan kesucian-Nya, Yesus Kristus telah menjadi korban ganti manusia yang berdosa sebagai konsekuensi logisnya.

Dengan kata lain, melalui kesucian Allah sendiri di dalam Yesus Kristus telah menyelamatkan manusia karena tidak ada seorang pun yang benar di hadapan Allah. Keselamatan yang telah diberikan seyogianya mendorong orang percaya untuk melakukan kesalehan dalam kehidupan sehari-hari ${ }^{5}$.

Rasa takut akan Allah hendaknya tertanam secara kuat di dalam diri orang percaya. Takut akan Allah ditunjukkan melalui kehidupan sebagai anak-anak yang taat dengan cara tidak menuruti hawa nafsu duniawi. Allah menghendaki manusia yang diselamatkan untuk hidup kudus dalam seluruh kehidupannya karena Tuhan adalah Kudus (Im. 11:44-45).

\footnotetext{
${ }^{5}$ http://www.ron-weber.com/Christian/Default.htm
} 


\section{METODE PENELITIAN}

Penulis menggunakan pendekatan penelitian yang bersifat kepustakaan (Library Research). Penelitian ini merupakan studi mengenai doktrin keselamatan yang benar, mengacu kepada pemahaman Teologi yang Alkitabiah serta pandangan tokoh-tokoh penulis buku yang memiliki pemahaman doktrin yang sesuai dengan Alkitab ajarkan.

\section{HASIL DAN PEMBAHASAN}

Kata kudus itu sendiri memiliki arti mengasingkan diri. ${ }^{6}$ Oleh karena itu, setiap orang yang sudah diselamatkan, diharapkan untuk tampil beda dengan dunia (Rm. 12:12). Ini merupakan dorongan yang kuat untuk menegaskan orang-orang Kristen dalam kehidupan rohani dan memacu untuk melakukan tugas-tugas kesalehan. Hidup kudus merupakan salah satu bukti dari karya kelahiran kembali dalam diri mereka.

Penghiburan merupakan salah satu akibat keselamatan yang begitu besar telah dikaruniakan oleh Allah sendiri. 1 Petrus 1:18-19 mengatakan, "Sebab kamu tahu, bahwa kamu telah ditebus dari cara hidupmu yang sia-sia yang kamu warisi dari nenek moyangmu itu bukan dengan barang yang fana, bukan pula dengan perak atau emas, melainkan dengan darah yang mahal,

${ }^{6}$ Athur W. Pink, Jaminan Kekal (Lawang: STT Tabernakel, 1996), 321. yaitu darah Kristus yang sama seperti darah anak domba yang tak bernoda dan tak bercacat."

Darah Yesus, Anak Allah yang tunggal, lebih berharga daripada apapun juga yang ada di dalam dunia ini. Namun Allah telah memberikannya kepada manusia yang berdosa. Paulus mengatakan bahwa Allah sendiri yang tidak menyayangkan Anak-Nya sendiri malahan menyerahkan-Nya bagi orang-orang percaya (Rm. 8:31). ${ }^{7}$

Oleh karena itu, Paulus yakin bahwa tidak ada yang dapat memisahkan orangorang yang sudah diselamatkan dari apapun juga termasuk penderitaan. Meskipun orang percaya mengalami penindasan, kesesakan, penganiayaan, kelaparan, ketelanjangan, bahaya atau pedang tapi kasih Allah tidak akan berpaling dari orang-orang percaya. ${ }^{8}$

Hal ini yang akan menjadi kekuatan serta penghiburan bagi orang-orang percaya bahwa Allah selalu hadir di dalam setiap pergumulannya. Penghiburan tatkala menghadapi pencobaan-pencobaan yang paling berat. Kasih Allah tidak akan pernah berpaling dari orang-orang yang telah diselamatkan-Nya. Keselamatan yang begitu besar menjadi jaminan bahwa Allah akan selalu menyertai orang percaya meskipun di dalam penderitaan.

\footnotetext{
${ }^{7}$ Ibid., 325.

${ }^{8}$ Ibid., 318-319.
} 


\section{Terhadap Sesama Orang Percaya.}

Orang Kristen yang sudah diselamatkan seharusnya menikmati dua dimensi persekutuan yaitu persekutuan dengan Allah dan manusia. Kata Yunani untuk persekutuan ialah koinonia yang berarti persahabatan, himpunan, partisipasi bersama, keakraban, kontribusi sesama atau pengumpulan. Dengan kata lain, kata ini merujuk kepada pemakaian sesuatu secara bersama-sama. Persekutuan yang merupakan manifestasi dari orang yang diselamatkan hendaknya mengikat sesama orang percaya menjadi satu tidak ada perpecahan meskipun adanya perbedaan. ${ }^{9}$

Perbedaan pemahaman akan doktrin keselamatan sering membawa pertikaian yang didasarkan pada kesombongan yang menganggap pemahamannya lebih superior sehingga tidak jarang mencemooh pandangan yang berbeda dengannya.

Mempelajari doktrin keselamatan seharusnya membawa kepada kerendahan hati karena Paulus telah mengajarkan, "Sebab karena kasih karunia kamu diselamatkan oleh iman; itu bukan hasil usahamu, tetapi pemberian Allah" (Ef 2:8).

Orang percaya seharusnya menyadari bahwa keselamatan merupakan

\footnotetext{
${ }^{9}$ Johannes Blauw, The Missionary Nature of The Church (New York: Broadman, 1966), 79.
}

pemberian $(\delta \tilde{\omega} \rho \circ \mathrm{v}$ diterjemahkan sebagai hadiah) dari Allah. Paulus dengan tegas mengatakan bahwa keselamatan bukanlah

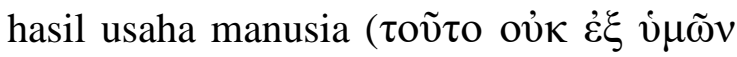
bukan berasal dari kamu sekalian/manusiamanusia).

Dengan kata lain, keselamatan semata-mata hanyalah anugerah dari Allah saja. Hal ini seharusnya tidak membawa kepada kecongkakan di dalam kehidupan praktis orang percaya namun hidup dengan ucapan syukur yang tiada henti-hentinya kepada Allah serta perdamaian dengan sesama (Ibr. 12:14). ${ }^{10}$

Oleh karena itu, pemahaman akan doktrin keselamatan yang baik seyogyanya menghasilkan praktek kehidupan rohani Kristiani yang baik pula. Dengan kata lain, untuk mengembangkan sikap rendah hati dan mau belajar sesuai dengan filosofi keselamatan yang Allah sudah berikan.

Dengan memiliki kerendahhatian dan sikap mau belajar, umat Tuhan bukan hanya semakin maju di dalam pertumbuhan spiritual, tetapi juga bertujuan meningkatkan persatuan antar umat Tuhan di Indonesia.

Perbedaan pemahaman teologi hendaknya tidak dijadikan perpecahan dan perselisihan tetapi keragaman. Di antara 
orang percaya pun seharusnya memiliki kasih yang tak bersyarat serta penerimaan satu dengan lainnya. ${ }^{11}$

Walaupun berbeda ajaran tetapi hendaknya tidak langsung menganggap sebagai bidat, dikucilkan bahwa dibunuh karena ajarannya tersebut. Dengan kata lain, kesombongan dan keegoisan dapat menyebabkan perpecahan di dalam umat Tuhan.

Allah menghendaki agar kiranya orang-orang yang telah diselamatkannya memiliki kerendahan hati untuk dapat menerima perbedaan serta kasih yang mempersatukan walaupun memiliki keberagaman ajaran tentang keselamatan itu sendiri. ${ }^{12}$

Hati seorang hamba yang rendah hati akan dipenuhi dengan kasih Allah dan diberi semangat oleh-Nya untuk memiliki persatuan di kalangan saudara-saudara seiman. ${ }^{13}$ Hal ini menyebabkan ketika sesama orang percaya yang secara jelas dan nyata telah berbuat dosa pun hendaknya diterima kembali dengan kasih dan membantu orang tersebut untuk mengalami pemulihan dari Allah sendiri.

Gereja mula-mula memperlihatkan kemuliaan Allah yang dinyatakan di dalam

\footnotetext{
${ }^{11} \mathrm{http} / / /$ www.oocities.org/tangkereid/art2.html

$12 \mathrm{http}: / /$ teologia.mystudylight.com/dilahirkankembali.html
}

kehidupan mereka. Kisah Para Rasul menyatakan bahwa "dan semua orang yang telah menjadi percaya tetap bersatu". Alkitab bahkan mencatat bahwa "segala kepunyaan" orang Kristen mula-mula adalah kepunyaan bersama. ${ }^{14}$

Tidak hanya itu, bahkan selalu ada dari mereka yang menjual harta miliknya lalu membagi-bagikannya kepada semua orang sesuatu dengan keperluan masingmasing. Kuasa Roh Kudus dalam kelahiran baru telah menghasilkan perubahan yang sedemikian radikal di dalam diri orangorang yang baru percaya tersebut sehingga mereka ingin berbagi setiap aspek kehidupan yang dimiliki untuk dinikmati bersama-sama. ${ }^{15}$

Ketamakan dan egosentris yang telah menandai kehidupan berdosa mereka telah digantikan oleh kehidupan bersama yang kudus, penuh kasih dan mengorbankan diri. Inilah yang mencari ciri utama kehidupan Kristiani yang telah diselamatkan. Allah telah menempatkan setiap orang dalam kehidupan ini untuk satu tujuan utama yaitu mengungkapkan kasihNya di tengah-tengah dunia yang tanpa kasih dan egois. Kasih Tuhan dinyatakan melalui pelayanan sesama orang percaya

\footnotetext{
${ }^{13}$ Johannes Blauw, The Missionary Nature of The Church, 81 .

${ }^{14} \mathrm{http}: / /$ renungan-kristen.blogspot.com/

15 C.E Autrey, Evangelism in Acts (Grand Rapids,

Michigan: Zondervan, 1964), 76.
} 
Jurnal Teologi \& Pelayanan ( Kerusso )

E-ISSN: 2714-9587

P-ISSN: 2407-554X

dan hal termulia yang mungkin dilakukan oleh orang percaya ialah melayani.

Ada beberapa contoh di dalam Alkitab yang mencatat tentang kehidupan Kristiani yang benar di hadapan Allah. Hust memberikan ringkasan tentang sikap-sikap yang harus dilakukan bagi mereka yang telah diselamatkan Tuhan kepada rekanrekan Kristiani lainnya yang terdapat di dalam Alkitab. ${ }^{16}$

Orang-orang percaya hendaknya selalu hidup berdamai dengan orang lain (Mrk. 9:5) karena kasih merupakan ciri khas dari ajaran Kristian (Rm. 12:10). Sesama saudara seiman hendaknya juga saling mendahului dalam arti mengutamakan orang lain sebagai anggota-anggota dari satu keluarga (Rm. 12:10). Kesatuan dalam pelayanan (Rm. 12:16) serta saling menerima satu dengan yang lain termasuk kelemahannya (Rm. 15:7) haruslah menjadi dasar kehidupan Kristiani. Saling menasehati (Rm. 15:14), saling membantu (Ef. 4:2), saling membangun satu dengan yang lainnya (1 Tes. 5:11) dan saling mendoakan (Yak. 5:16) harus dilakukan untuk memperkuat hubungan antara saudara-saudara seiman. ${ }^{17}$

\footnotetext{
${ }^{16}$ D.S Hust \& T.J Jones, The Church Begins (Springfield: Gospel Pub. 1959), 126-128. ${ }^{17}$ Ibid., 129.

${ }^{18} \mathrm{http}: / /$ renungan-kristen.blogspot.com/2011/03/takada-alasan-untuk-tak-hidup-kudus.html
}

Walaupun orang-orang tersebut mungkin telah melukai hati banyak orang, tetapi juga orang percaya bukanlah mendendam, tetapi justru menolong serta mendoakan. Orang percaya haruslah penuh kasih mesra dan saling mengampuni satu dengan yang lainnya (Ef. 4:32).

Meskipun hati telah terluka dan disakiti tetapi pengampunan yang Allah telah berikan untuk keselamatan orang percaya seharusnya menjadi dasar pengampunan orang percaya terhadap sesamanya. ${ }^{18}$ Merendahkan diri terhadap yang lain juga menjadi faktor kunci dalam hubungan antar sesama orang beriman (Ef. 5:21) bukan justru menganggap diri paling pandai dan hebat. Tetapi hendaklah saling menghormati satu dengan yang lain dengan hati yang terbuka (1 Pet. 5:5). ${ }^{19}$ Inilah halhal yang diberikan oleh Alkitab terhadap sesama saudara seiman sebagai manifestasi keselamatan yang Tuhan sudah berikan.

Kitab Suci tidak hanya berbicara tentang hal-hal yang harus dilakukan tetapi juga berbicara tentang hal-hal yang tidak boleh dilakukan. Ada beberapa hal yang tidak boleh dilakukan yang Alkitab katakan. Kitab Suci mengajarkan agar orang percaya tidak saling menghakimi lagi (Rm. 14:13)

\footnotetext{
${ }^{19}$ D.S Hust \& T.J Jones, The Church Begins, 130133.
} 
namun saling memberkati dan memberi dorongan satu dengan yang lainnya. Tidak hanya itu, tetapi juga jangan lagi saling mendustai (Kol 3:9), saling membenci (Tit. 3:3) maupun saling memfitnah (Yak. 4:11). Semua itu bukanlah cerminan dari orangorang yang belum diselamatkan. ${ }^{20}$ Alkitab mencatat bahwa sesama orang percaya hendaknya saling membangun bukan saling menjatuhkan satu dengan yang lainnya.

Dalam setiap hal, perintah dan nasihat Kitab suci mengenai hubungan orang Kristen satu dengan yang lainnya dapat disimpulkan dalam satu frase yaitu kasihilah sesamamu manusia seperti dirimu sendiri. Yesus memanggil dan memberi kuasa kepada orang-orang yang telah diselamatkan-Nya untuk mengasihi sesama saudaranya sebagainya Ia telah mengasihi umat-Nya terlebih dahulu. Ia meminta agar kiranya orang percaya hidup tanpa keangkuhan dan egoisme yang tinggi namun mencurahkan kehidupan mereka bagi sesamanya. ${ }^{21}$ Inilah hukum kasih. Yohanes mengatakan, "Aku memberikan perintah baru kepada kamu, yaitu supaya kamu saling mengasihi; sama seperti Aku telah mengasihi kamu demikian pula kamu harus saling mengasihi."

\footnotetext{
${ }^{20}$ Lesslie Newbigin, The Household of God (New York: Friendship, 1953), 323-324.

${ }^{21}$ Ibid.
}

35 Dengan demikian semua orang akan tahu, bahwa kamu adalah murid-murid-Ku, yaitu jikalau kamu saling mengasihi." Semua orang Kristen merupakan bagian dari tubuh Kristus yang sama. Mereka adalah anggota satu dengan yang lagi dan saling memiliki. ${ }^{22}$

Oleh karena itu, persekutuan di dalam Perjanjian Baru tidak hanya ibadah hari minggu saja tetapi juga melibatkan akan cara hidup Kristiani secara keseluruhan yang Alkitabiah. ${ }^{23}$ Persekutuan ini kemudian mempersatukan oang Kristen bersama di hadapan hadirat Allah dan dengan ciri khas kehidupan yang seperti ini akan menjadi terang dan garam bagi dunia.

\section{Terhadap Gereja Tuhan Di Indonesia}

Ada begitu banyak denominasi gereja di Indonesia. Setiap denominasi memiliki sistem teologi dan juga kehidupan gerejawi yang berbeda-beda. Namun pemahaman akan doktrin keselamatan yang benar dapat menolong gereja Tuhan untuk memiliki sikap yang sesuai dengan Alkitab. Ada tiga denominasi gereja yang akan dibahas yaitu Calvin, Armenian dan juga Karismatik.

\footnotetext{
${ }^{22} \mathrm{http} / / /$ sumberkristen.com/Mimbar\%20Gereja/mim bar\%20gereja\%205/kesatuan\%20umat\%20Tuhan.ht $\mathrm{m}$

${ }^{23}$ Ibid., 326-327.
} 
Bagi pengikut teologi Calvin, mereka harus memiliki kerendahan hati, bahwa ajaran keselamatan Calvin tidaklah Alkitabiah secara khusus tentang mereka yang binasa. Para pengikut Calvin harus berani mengakui akan kekeliruan ajaran Calvin sendiri melalui pemeriksaan yang mendalam terhadap ayat-ayat Alkitab yang menjadi dukungan bagi ajaran predestinasi ganda. ${ }^{24}$ Tidak hanya itu, mereka pun harus lebih mencintai ajaran Alkitab itu sendiri di atas ajaran Calvin. Apabila ajaran Calvin tidak sesuai dengan kebenaran Firman Allah maka mereka harus terbuka dan berani untuk berubah.

Bagi

pengikut aliran Armenian yang merupakan kebalikan dari ajaran Calvin harus menyadari bahwa manusia diselamatkan bukan berdasarkan dari kebaikan atau perbuatan manusia tetapi berdasarkan pada anugerah Allah yang tercurah pada hidup orang-orang percaya. Oleh karena itu, setiap pengikut Armenian harus menyadari bahwa keselamatan dapat membuatnya untuk memegahkan diri sendiri. Manusia sungguh bergantung penuh kepada Allah dalam keselamatannya. $^{25}$

Banyak orang berpikir bahwa manusia itu pada dasarnya dilahirkan baik

\footnotetext{
${ }^{24}$ http://gkjwkm.org/2011/02/membangun-hidupdalam-kesatuan-roh-dan-damai-sejahtera/ ${ }^{25} \mathrm{http}$ ///www.ifgf.org/index.php/in/news-topmenu82/articles-blogs-sermons/81-articles/933-how-tobuild-unity
}

dan ia menjadi jahat karena lingkungan yang telah mempengaruhinya. Akan tetapi semua yang telah terjadi pada keluarga Adam dan Hawa yang merupakan keluarga pertama di dunia ini mematahkan pandangan tersebut. Mereka memiliki anak laki-laki yang bernama Habel dan Kain (Kej 4:1-16).

Jika memang lingkungan yang mempengaruhi seseorang berbuat dosa, bisa dikatakan keluarga ini tidak memilki lingkungan di mana mereka bisa melihat kejahatan dan keboboran orang lain yang berakibat buruk pada mereka. Namun yang pasti tabiat berdosa seperti rasa cemburu dan dengki yang merupakan sifat alami atau tabiat yang diakibatkan kejatuhan Adam dan Hawa telah diturunkan kepada anakanak mereka. Akibatnya, pembunuhan pertama yang sangat tragis terjadi pada keluarga Adam dan Hawa dimana Kain membunuh adiknya sendiri, Habel, dan menguburnya sendiri (Kej 4:8). ${ }^{26}$

Dan ketika Allah mengkonfrontasi Kain tentang adiknya, ia bersikap seperti tidak terjadi apa-apa di antara mereka. Inilah bukti bahwa manusia telah memiliki sifat dan tabiat berdosa, dan kejahatan manusia bukanlah akibat lingkungan yang

\footnotetext{
${ }^{26}$ http://katolisitas.org/2008/06/10/bagaimanacaranya-untuk-hidup-kudus/
} 
Jurnal Teologi \& Pelayanan ( Kerusso )

E-ISSN: 2714-9587

P-ISSN: 2407-554X

buruk dan jahat, karena Kain dan Habel

hidup ketika masih belum ada lingkungan yang mempengaruhi mereka.

Kejatuhan manusia ke dalam dosa menjadikan manusia tidak lagi mampu untuk melakukan perbuatan baik atau kebajikan sejati yang sesuai dengan standar Allah (Ini tidak berarti manusia tidak bisa berbuat baik kepada sesama manusia mampu melakukan itu, tetapi sebesar apapun pekerjaan baik yang diperbuat tidak akan pernah menjadi kebajikan sejati yang bisa menyelamatkan diri mereka sendiri. ${ }^{27}$

Allah mengetahui bahwa manusia itu tidak akan mampu mengerjakan perintah Allah dengan sempurna sehingga Ia menjanjikan Mesias yang akan mati sebagai pengganti manusia untuk menebus mereka dari dosa (Kejadian 3:15).

Kristus adalah Mesias yang dijanjikan Allah. Dialah yang mampu mengerjakan semua tuntutan perintah Allah agar manusia itu bisa diselamatkan dan memperoleh hidup kekal. Dan inilah yang Paulus katakan sebagai anugerah Allah kepada manusia melalui iman dalam Yesus Kristus. Mereka yang telah percaya pada Kristus sadar bahwa bukan karena usaha keras dan perbuatan baik sehingga mereka memperoleh hidup kekal tetapi karena
Allah mengasihi dan menganugerahkan keselamatan itu kepada mereka (Yoh $3: 16) .^{28}$

Di dalam Efesus 2:8-10, Paulus mengemukakan dua bagian penting yaitu keselamatan itu sepenuhnya karya Allah dan juga pekerjaan baik yang orang percaya harus lakukan. "Karena kita ini buatan Allah, diciptakan dalam Kristus untuk melakukan pekerjaan baik yang dipersiapkan Allah sebelumnya. Ia mau, supaya kita hidup di dalamnya." (Ef 2:10). Maksud ayat ini ialah setiap orang yang diciptakan (diselamatkan) dalam Kristus harus melakukan pekerjaan baik dan harus berusaha hidup di dalamnya. ${ }^{29}$

Dengan kata lain, setelah seseorang diselamatkan ia harus melakukan perbuatan baik dan harus menjadi bagian dari kehidupannya, bukan untuk menyelamatkannya tetapi sebagai bukti bahwa ia sungguh-sungguh percaya pada Yesus.

Setiap orang percaya harus berkomitmen dan berdedikasi untuk itu. Semakin dewasa kerohanian seseorang akan semakin tinggi dedikasinya untuk melakukan perbuatan baik. Pekerjaan baik sedemikian merupakan suatu aplikasi

\footnotetext{
${ }^{27}$ Ibid.

${ }^{28}$ http://teologia.mystudylight.com/dilahirkan-

kembali.html
} 
ketaatan seseorang pada apa yang diterima dan dipelajari dari firman Allah.

Dengan sadar, sesulit apapun perintah Allah ia harus belajar menaatinya sesempurna mungkin, dan Roh Kudus akan memampukannya untuk terus menaati firman Allah. Ini merupakan buah pembaharuan dalam diri seorang percaya. Seperti Paulus berkata, "Jadi siapa yang ada di dalam Kristus, ia adalah cipataan baru: yang lama sudah berlalu, sesungguhnya yang baru sudah datang" (2 Kor 5:17). ${ }^{30}$

Jika sebelumnya tidak pernah berkeinginan untuk melakukan perbuatan baik, maka ia berubah dan berdedikasi untuk itu. Pengalaman seperti ini pasti dirasakan setiap orang percaya. Seorang yang tadinya jahat berubah menjadi pelaku kebaikan, tadinya pemarah berubah menjadi lemah lembut, tadinya kejam berubah menjadi penuh kasih, tadinya tidak memperdulikan orang lain berubah menjadi penuh perhatian dan pendoa yang luar biasa bagi orang lain.

Semua ini merupakan pembaharuan dalam diri orang percaya Paulus kembali menegaskan dalam tulisannya kepada Titus, "Perkataan ini benar dan aku mau supaya engkau dengan yakin menguatkannya agar mereka yang sudah percaya kepada Allah sungguh-sungguh berusaha melakukan pekerjaan baik. Itulah yang baik dan berguna bagi manusia” (Tit 3:8). Perkataan ini disampaikan Paulus setelah menegaskan bahwa keselamatan itu (hidup kekal) merupakan anugerah Allah melalui Yesus Kristus (Titus 3:5-7). ${ }^{31}$

Dalam 2 Timotius 3:16, Paulus menjelaskan manfaat firman Allah yaitu untuk mengajar, menyatakan kesalahan, memperbaiki kelakuan dan mendidik orang dalam kebenaran, namun tujuan akhir dari manfaat ini adalah agar "tiap-tiap manusia kepunyaan Allah diperlengkapi untuk setiap perbuatan baik" (2 Tim 3:17). Dengan demikian, tidak ada alasan bagi umat Kristen untuk tidak melakukan pekerjaan baik. Setiap perbuatan baik harus dilakukan bagi kemuliaan Allah dan selain dari tujuan ini, semua pekerjaan baik tidak ada yang berkenan kepada Allah.

Ketika umat Kristen telah mengetahui dengan benar bahwa keselamatan itu bukan hasil usaha atau perbuatan mereka, maka umat Kristen harus menyadari juga bahwa Allah yang sama memberikan perintah agar mereka juga melakukan perbuatan baik. Semakin dewasa iman dan kerohanian seseorang maka semakin mudah bagi mereka untuk melakukan perbuatan baik bagi sesama jemaat maupun di luar jemaat. ${ }^{32}$

\footnotetext{
${ }^{32}$ Lesslie Newbigin, The Household of God, 340.
} 
Seperti Paulus berkata, "Janganlah kita jemu-jemu berbuat baik, karena apabila sudah datang waktunya, kita akan menuai. Jika kita tidak menjadi lemah. Karena itu, selama masih ada kesempatan bagi kita, marilah kita berbuat baik kepada semua orang, tetapi terutama kepada kawan-kawan kita seiman" (Gal 6:9-10). ${ }^{33}$ Dengan latar belakang pengertian ini, maka akan lebih mudah mengerti apa yang Yesus katakan tentang peranan orang percaya sebagai terang dunia. Yesus berkata demikian, "Kamu adalah terang dunia ... Dengan demikian hendaknya terangmu bercahaya di depan orang, supaya mereka melihat perbuatanmu yang baik dan memuliakan Bapamu yang di sorga." (Mat 5:14-16).

Melakukan perbuatan baik merupakan perintah Yesus dan umat Kristen tidak bisa dengan alasan apapun menghindari pekerjaan baik. Ada suatu tuntutan dimana setiap umat Kristen harus terus bersinar di mana pun mereka berada. Mereka harus berani membuat suatu perbedaan di antara orang-orang yang tidak mengenal Kristus sebagai bukti pembaharuan yang dikerjakan Roh Kudus dalam diri mereka. ${ }^{34}$ Orang Kristen harus berlomba-lomba untuk melakukan

\footnotetext{
${ }^{33} \mathrm{http}: / /$ teologia.mystudylight.com/hidup-kekal-danperbuatan-baik.html ${ }^{34}$ Ibid.
}

pekerjaan baik terutama di tengah-tengah jemaat Tuhan. ${ }^{35}$

Alkitab mencatat banyak contoh tentang mereka yang melakukan perbuatan baik sebagai bukti iman dan keselamatan yang mereka miliki. Berikut ini ada tiga contoh yang bisa dipertimbangkan.

Pertama ialah Dorkas, "Di Yope ada seorang murid perempuan bernama Tabita dalam bahasa Yunani Dorkas. Perempuan itu banyak sekali berbuat baik dan memberi sedekah” (Kisah 9:36). Di masa itu, para janda merupakan kelompok orang-orang lemah dan kurang diperdulikan. Kematian suami seorang janda telah mengubah statusnya dan menjadi kurang diharga dan diterima masyarakat. Dorkas melakukan perbuatan baik kepada para janda di mana ia membuatkan baju dan pakaian bagi mereka dan perbuatan ini baru diketahui orang banyak ketika ia meninggal dunia. ${ }^{36}$

Kedua ialah Febe, "Aku meminta perhatianmu terhadap Febe, saudari kita yang melayani jemaat di Kengkrea, supaya kamu menyambut dia dalam Tuhan, sebagaimana seharusnya bagi orang-orang kudus, dan berikanlah kepadanya bantuan bila diperlukannya. Sebab ia sendiri telah memberikan bantuan kepada banyak orang, juga kepadaku sendiri” (Roma 16:1-2). Para

\footnotetext{
${ }^{35}$ Ibid.

${ }^{36} \mathrm{http}: / /$ ccamedan.org/artikelinti.php?id=132\&lang=
} 
komentator mempercayai Febe sebagai seorang diakenes yang melayani Tuhan. Meskipun seorang wanita, namun ia dapat dipercaya. Banyak penafsir Alkitab mempercayai Febe adalah orang yang membawa surat Paulus kepada jemaat Roma. Febe menginginkan orang Roma memiliki kebenaran Firman Allah dan ia melakukan perjalanan yang begitu jauh Kengkrea menuju Roma. ${ }^{37}$

Ketiga ialah Epafras, "Salam dari Epafras kepada kamu; ia seorang dari antaramu, hamba Kristus Yesus, yang selalu bergumul dalam doanya untuk kamu, supaya kamu berdiri teguh, sebagai orangorang yang dewasa dan yang berkeyakinan penuh dengan segala hal yang dikehendaki Allah. ..., bahwa ia sangat bersusah payah untuk kamu dan untuk mereka yang di Laodikia dan Hierapolis" (Kol 4:12-13). Epafras adalah seorang pelayan yang memperdulikan pertumbuhan kerohanian orang lain. Dia mau bergumul dalam doa untuk orang lain. Ia seorang jemaat yang terbeban untuk pelayanan dan merindukan pertumbuhan rohani umat Tuhan. Dia mau bersusah payah bagi orang lain yaitu jemaat Laodikia dan Hierapolis. ${ }^{38}$ Dengan demikian, orang Kristen harus berlombalomba untuk melakukan pekerjaan baik

${ }^{37}$ Ibid.

${ }^{38}$ Ibid. bukan untuk memperoleh keselamatan tetapi sebagai manifestasi keselamatannya.

Bagi pengikut aliran karismatik, sering kali menganggap bahwa Roh Kudus bisa meninggalkan seseorang dan keselamatan manusia bisa hilang. Menurut mereka, pendiaman Roh Kudus itu tidak bersifat parmanen tetapi bersifat kondisional yang artinya Roh Kudus itu akan mendiami hati seorang percaya jika ia kudus dan berkenan kepada Allah. Akan tetapi ketika ia melakukan dosa dan tidak taat kepada Kristus, Roh Kudus itu akan meninggalkannya. ${ }^{39}$

Inilah pandangan yang keliru tentang pendiaman Roh Kudus dalam diri orang percaya karena pandangan ini menekankan pada kemampuan manusia untuk menjaga dan memelihara Roh Kudus yang berdiam dalam dirinya. Apabila ia tidak mampu melakukannya maka ia akan kehilangan Roh Kudus. Kelompok yang mempercayai ajaran ini akan mengatakan bahwa jika Roh Kudus telah meninggalkan seseorang maka ia juga akan kehilangan keselamatan dan hidup kekal. ${ }^{40}$

Ajaran ini berfokus pada kemampuan manusia untuk memelihara imannya dan jika ia gagal maka ia akan kembali pada status seperti seorang yang

\footnotetext{
${ }^{39} \mathrm{http} / /$ teologia.mystudylight.com/hidup-kekaldan-perbuatan-baik.html ${ }^{40}$ Ibid.
} 
belum percaya. Itulah sebabnya di banyak gereja, ketika KKR (Kebaktian Kebangunan Rohani) diselenggarakan ada banyak orang yang ingin menerima Tuhan Yesus Kristus sebagai Tuhan dan Juruselamat pribadinya.

Anehnya, banyak diantara mereka yang telah menjadi pengurus dan majelis gereja dan sudah aktif melayani di gerejanya dan sebagainya. Tetapi karena mereka mempercayai ajaran yang keliru maka mereka harus menerima Kristus kembali sama seperti orang-orang yang belum mengenal Kristus. Bahkan ada orang-orang tertentu yang dengan rajin menghadiri KKR yang diselenggarakan diberbagai gereja dan setiap ada undangan untuk percaya, ia akan selalu ikut di dalamnya. ${ }^{41}$

Penjelasan untuk pandangan ini terdapat di dalam beberapa ayat Alkitab. Roma 8:9 merupakan ayat penting dalam pelajaran ini karena setiap orang yang telah diselamatkan tidak hidup dalam daging tetapi hidup dalam Roh dan Paulus menegaskan demikian, "Tetapi jika orang tidak memiliki Roh Kristus, ia bukanlah milik Kristus."

Jika Allah hanya memberikan satu Juruselamat yaitu Yesus Kristus, maka Yesus jugalah Juruselamat di Perjanjian

\footnotetext{
${ }^{41} \mathrm{http} / / / \mathrm{www}$. oocities.org/thisisreformed/artikel/hm ngzb.pdf
}

Lama dan Perjanjian Baru. Setiap orang yang percaya pada Kristus adalah sungguhsungguh milik Kristus yang ditebus melalui hidup dan pengorbanan-Nya di kayu salib dan darah-Nya yang tercurah telah membayar lunas semua hutang dosanya. ${ }^{42}$

Dengan kata lain setiap orang yang ada di sorga saat ini dan masa yang akan datang adalah mereka yang di masa hidupnya memiliki Roh Kudus berdiam dalam dirinya (1 Kor 3:16; 2 Kor 6:14). Roh Kudus menghibur, membimbing dan menguatkan orang percaya di dalam menjalani hidupnya. Pendiaman Roh Kudus dalam diri seorang percaya membuatnya berbeda dengan orang-orang yang tidak percaya pada Yesus (1 Yoh 4:4).

Roh Kudus yang ada di dalam diri setiap orang percaya akan berdiam secara parmanen selama orang itu hidup. Paulus menegaskan demikian, "Di dalam Dia kamu juga - karena kamu telah mendengar firman kebenaran, yaitu Injil keselamatanmu-di dalam Dia kamu juga, ketika kamu percaya, dimeteraikan dengan Roh Kudus, yang dijanjikan-Nya itu. Dan Roh Kudus itu adalah jaminan bagian kita sampai kita memperoleh seluruhnya, yaitu penebusan yang menjadikan kita milik Allah, untuk memuji kemuliaan-Nya" (Ef 1:13-14).

\footnotetext{
${ }^{42} \mathrm{http}: / /$ teologia.mystudylight.com/hidup-kekaldan-perbuatan-baik.html
} 
Paulus berkata bahwa mereka yang telah dinyatakan menjadi milik Kristus akan memiliki Roh Kristus atau Roh Kudus dan jika seseorang itu tidak memiliki Roh Kristus (Roh Kudus) maka ia bukanlah milik Kristus dan ia tidak akan pernah masuk dan melihat kerajaan sorga (Yoh $3: 5){ }^{43}$

Oleh karena Allah yang menganugerahkan keselamatan dan pendiaman Roh Kudus dalam diri orang percaya maka Allah berdaulat penuh atas keselamatan orang percaya. Dialah yang memilih setiap orang percaya dan pemilihannya itu mutlak sebagai wewenang Allah. Allah itu kekal dan tidak berubah. Oleh karena itu, segala yang Ia tetapkan tidak akan pernah berubah.

Keselamatan yang diberikan kepada orang percaya tidak akan pernah dicabut meskipun ia memiliki kelemahan sebagai orang Kristen. Setiap kesalahan dan dosa yang diperbuat orang Kristen akan diampuni jika ia mengakuinya (1 Yoh 1:9) tetapi konsekuensi dari perbuatannya akan ditanggungnya, namun ia akan tetap selamat (1 Kor 3:10-15). ${ }^{44}$

Di samping itu, pengudusan manusia ada tiga macam yaitu secara posisi,

\footnotetext{
${ }^{43}$ Ibid.

${ }^{44}$ http://renungan-kristen.blogspot.com/

${ }^{45} \mathrm{http}$ ///bible.org/seriespage/session-9-doctrinesanctification
}

progresif maupun pemuliaan di masa datang. Keselamatan orang percaya sudah pasti diperoleh karena secara posisi telah diselamatkan tatkala percaya pada Yesus Kristus. $^{45}$

Akan tetapi, di dalam perjalanan kehidupan sebagai orang percaya, perlu adanya perbuatan-perbuatan baik sebagai manifestasi dari keselamatan yang telah diperoleh. Perbuatan baik ini bukan untuk mempertahankan keselamatan karena secara posisi, orang percaya telah diselamatkan. Namun perbuatan baik ini dilakukan sebagai proses dari pengudusan dalam kehidupan ini. Jadi, baik posisi maupun proses pengudusan orang percaya memang dapat dibedakan tetapi tidak dapat dipisahkan di dalam doktrin keselamatan. ${ }^{46}$

Apabila hal ini dipahami dengan baik, maka tidak ada kekhawatiran mengenai masuk atau tidaknya seseorang ke dalam Surga karena secara posisi sudah menjamin. Konsep akan doktrin keselamatan bukan hanya mengarahkan tindakan yang benar tetapi juga memberikan ketenangan serta jaminan bahwa keselamatan orang percaya dimeteraikan oleh Pribadi Ketiga dari TriTunggal sendiri.

\footnotetext{
${ }^{46} \mathrm{http}$ ///bible.org/seriespage/kepastian-tentangkeselamatan
} 
Bagi orang yang sudah diselamatkan, Roh Kudus tinggal di dalam setiap orang percaya, dan Ia selalu aktif menggerakkan dan membimbing kehidupan orang-orang percaya untuk melakukan halhal yang sesuai dengan Firman Tuhan (Rm $8: 14){ }^{47}$

Orang percaya dapat memadamkan atau menaati pekerjaan Roh Kudus. Memadamkan pekerjaan Roh Kudus berarti ia lebih memilih hidup menuruti keinginan daging, yaitu perbuatan-perbuatan yang tidak sesuai dengan Firman Tuhan. Menaati Roh Kudus berarti orang percaya memilih hidup menuruti keinginan Roh Kudus, yaitu perbuatan-perbuatan yang sesuai Firman Tuhan (Ef 5:18). ${ }^{48}$

Dengan demikian, orang percaya harus berbuat baik bukan untuk mempertahankan keselamatan, tetapi sebagai manifestasi anugerah hidup kekal yang Allah telah berikan. Inilah pemahaman yang harus dimengerti oleh aliran karismatik.

\section{KESIMPULAN}

Keselamatan berasal dari rencana kekal Allah sendiri, namun keselamatan dalam sejarah disediakan melalui pribadi

\footnotetext{
${ }^{47}$ http://bible.org/seriespage/session-9-doctrinesanctification 48

http://christianreformedink.wordpress.com/reforme
}

dan karya Kristus, Anak Allah yang kekal. Roh Kudus sendiri yang menjaga dan memeteraikan akan keselamatan yang Allah telah berikan kepada manusia.

Akan tetapi, dalam perkembangan kekristenan, ada banyak gereja yang tidak lagi memfokuskan penginjilan dalam program gereja. Program penginjilan sering diabaikan. Kerinduan melihat orang lain memperoleh keselamatan telah menjadi pudar, sehingga banyak keluarga Kristen tidak lagi memperhatikan anggota keluarga atau anak-anaknya yang belum percaya pada Yesus Kristus. Banyak orang Kristen tidak lagi menyadari bahwa tiap-tiap orang harus mengakui secara pribadi bahwa Kristus adalah Tuhan dan Juruselamatnya. ${ }^{49}$ Ada suatu waktu di mana seseorang menyadari bahwa tanpa Kristus, ia akan binasa karena tidak bisa menyelamatkan dirinya dengan kekuatan, hikmat dan perbuatannya. Ia harus sadar bahwa ia seorang berdosa yang memerlukan Tuhan dan Juruselamat yang bisa menghapus segala dosa-dosanya agar terlepas dari kutuk dosa (Roma 6:23).

Oleh karena itu, alasan pertama untuk memberitakan Injil kepada orang yang tidak percaya ialah karena rasa syukur

d-theology-2/pneumatology/doktrin-roh-kudus-dankehidupan-orang-percaya-ind/

${ }^{49} \mathrm{http}$ ://bible.org/seriespage/adorned-true-beauty-5adorned-beauty-among-unbelievers 
atas keselamatan yang Ia telah berikan. Tidak ada satu pun dari diri manusia yang dapat membuang Tuhan berpaling kepadanya. ${ }^{50}$ Tetapi dengan kasih-Nya, Ia rela menderita dan mati bagi umat manusia yang berdosa. Rasa syukur akan kebaikan Allah semestinya membuat orang-orang percaya termotivasi untuk memberikan Injil kepada mereka yang masih belum percaya. $^{51}$

Alasan kedua ialah rasa hormat atas Allah yang berkuasa dengan menyelamatkan manusia yang berdosa untuk memperoleh kehidupan kekal. Allah Tritunggal bukan hanya telah memberikan keselamatan kepada orang-orang percaya, tetapi juga mandat yaitu memberitakan Injil. Pemberitaan Injil merupakan unsur yang tidak dapat dipisahkan dari panggilan keselamatan dan ketaatan kepada amanat agung Kristus. ${ }^{52}$

Hal ini dikarenakan pelayanan pemberitaan Injil sejati dan yang berhasil hanya dapat dilakukan oleh orang-orang yang telah diperbaharui oleh Roh Kudus. Orang-orang percaya telah dipercayakan untuk menjadi saksi-saksi dan para utusan Kristus. Berita yang dibawakan ialah pesan

\footnotetext{
${ }^{50} \mathrm{http}$ ://bible.org/seriespage/spread-gospel-romans1514-33

${ }^{51}$ Nels F.S Ferre, Fear, Duty and Love as Ultimate Motives for Christian Missions (Grand Rapids: Baker Academic, 1948), 393-402.
}

yang diwahyukan mengenai karya penebusan Allah di dalam Kristus Yesus.

Alasan ketiga ialah adanya rasa belas kasih terhadap orang-orang yang belum percaya. Rasa belas kasih seringkali ditunjukkan kepada orang-orang yang berusaha keras beribadah untuk memperoleh keselamatan di surga. Tetapi kerja keras mereka tidak menghasilkan keselamatan apapun. ${ }^{53}$

Segala ibadah yang dijalankan selama berpuluh-puluh tahun menjadi siasia ketika meninggal. Hal ini seharusnya membuat orang percaya sedih dan berbelas kasihan kepada mereka karena keselamatan yang diterimanya dengan cuma-cuma dan gratis dari pihak manusia. Tidak hanya itu, tetapi juga mendorong orang percaya untuk semakin giat memberitakan kabar baik dan kesukaan bahwa dosa-dosa mereka akan diampuni apabila menerima Kristus menjadi Juru Selamat.

Rasa belas kasihan juga akan muncul apabila orang percaya mengingat akan kebinasaan kekal yang akan dialami oleh orang-orang yang tidak percaya. Mereka akan dihukum dalam lautan api selama-lamanya tanpa batas. ${ }^{54}$ Oleh karena

\footnotetext{
${ }^{52}$ George W. Peters, A Biblical Theology of Missions (Malang: Gandum Mas, 2006), 194-196.

${ }^{53} \mathrm{http} / / /$ bible.org/seriespage/adorned-true-beauty-5adorned-beauty-among-unbelievers

${ }^{54}$ Julian Love, The Missionary Message of The Bible (New York: Macmillan, 1941), 89.
} 
itu, hal-hal inilah yang seharusnya mendorong orang percaya untuk dapat memberitakan keselamatan, seperti yang ia telah dapatkan, kepada orang lain supaya mereka tidak binasa.

Pemberitaan Injil hendaknya berfokus kepada pembebasan rohani dan pemulihan manusia seutuhnya. Masalah dosa dan rasa bersalah dapat diselesaikan melalui penerimaan Kristus sebagai Juru Selamat. ${ }^{55}$

Oleh karena itu, setiap orang percaya oleh Tuhan harus terlibat di dalam memproklamirkan Injil secara intensif maupun ekstensif kepada segala bangsa. Dengan memberitakan kabar baik tersebut, diharapkan agar orang-orang yang diinjili dapat mengalami anugerah Allah yang sediakan oleh kematian dan kebangkitan Yesus Kristus dalam bentuk pengampunan atas dosa-dosa mereka.

Amanat Agung Yesus Kristus tidak hanya berhenti sampai hanya pada pemberitaan saja tetapi juga melibatkan pengajaran. Tujuan pengajaran ini ialah untuk menuntun orang yang baru percaya untuk meninggalkan kebiasaan-kebiasaan dosa yang terdahulu dan hidup sesuai dengan kebenaran Alkitab.

\footnotetext{
${ }^{55}$ George W. Peters, A Biblical Theology of Missions, 204.

${ }^{56}$ H.W Gensichen, Living Missions (Philadelphia: Fortress, 1966), 104.
}

Pengajaran hendaknya membuat mereka untuk menghargai keselamatan serta anugerah yang Allah telah berikan serta melayani Tuhan dengan karuniakarunia Roh. ${ }^{56}$ Jadi, ada dua aspek penting di dalam pemberitaan Injil yaitu menyampaikan Firman Tuhan bagi mereka yang belum percaya sekaligus mengajarkannya.

Pemberitaan Injil ini dapat dilakukan dengan pengutusan, penginjilan, pelatihan murid-murid maupun perintisan gereja. Alkitab mencatat beberapa contoh penginjilan melalui pengutusan kedua belas murid (Mat. 10:1-20; Mrk. 3:13-19; Luk. 6:12-16), pengutusan tujuh puluh murid (Luk. 10:1-20), pengutusan kembali dua belas murid (Mat. 16:14-18; Luk. 24:36-49; Yoh. 20:19-23; Kis. 1:7-8) serta pengutusan Paulus (Kis. 9:1516; 26:14-20). ${ }^{57}$

Pengutusan ini bertujuan untuk memberitakan Injil Kristus kepada orangorang yang tidak percaya melalui saksisaksi yang telah dibina dan diperlengkapi terlebih dahulu. Pengutusan untuk memberitakan Injil jauh lebih baik apabila melibatkan sebuah tim.

Maksudnya ialah bekerja bersamasama dengan orang-orang yang memiliki

\footnotetext{
${ }^{57}$ George W. Peters, A Biblical Theology of Missions, 204.
} 
pelayanan dan peran yang berbeda-beda supaya menghasilkan pelayanan lengkap sehingga dapat memenuhi kebutuhan rohani orang banyak secara utuh. ${ }^{58}$

Apabila sebuah tim pelayanan pemberita Injil ini dapat dimaksimalkan sebaik mungkin maka akan dapat mempercepat produktivitas. Lebih banyak pelayanan yang dapat terselesaikan oleh beberapa orang yang saling bekerja sama dan terkoordinasi. ${ }^{59}$

Penginjilan bersifat dua dimensi yaitu memberitakan Injil kepada orang banyak (Kis. 8:1-13) dan bersaksi secara perseorangan (Kis. 8:26-40). Inti dari dimensi penginjilan ini ialah pemberitaan Injil dapat disampaikan dengan beberapa cara yaitu langsung kepada kelompok yang besar seperti kebaktian kebangunan rohani maupun secara perseorangan. ${ }^{60}$

Apapun metodenya, pesan Injil tersebut tetap Yesus dan tujuannya ialah untuk memberitakan Injil kepada segala bangsa. Pelatihan murid-murid dijalankan dengan cara mengajarakan ajaran-ajaran awal tentang iman Kristen serta penanaman akan kerinduan untuk memberitakan Injil kepada orang-orang yang tersesat. Perintisan jemaat juga dapat dilakukan

\footnotetext{
${ }^{58}$ Dick Iverson, Gereja Sehat dan Bertumbuh (Malang: Gandum Mas, 2003), 79.

${ }^{59}$ Ibid., 80.
}

dengan membentuk jemaat rumah tangga biasa menjadi jemaat kecil. Tidak hanya itu, orang-orang yang baru percaya ini harus dididik dan didorong untuk menyampaikan kesaksian Injil kepada masyarakat di sekitarnya. $^{61}$

Dengan kata lain, mobilisasi dan pelatihan orang-orang awam untuk menjadi penginjil adalah kunci penyebarluasan gerakan ini. Dengan demikian, ada beberapa metode atau cara memberitakan Injil sebagai manifestasi ucapan syukur keselamatan yang telah diberikan.

\section{DAFTAR PUSTAKA}

[1] Autrey, C.E. Evangelism in Acts. Grand Rapids, Michigan: Zondervan, 1964

[2] Berkof, Louis Berkof, Doktrin Keselamatan. Jakarta: Lembaga Reformed Injili Indonesia, 1997.

[3] Blauw, Johannes. The Missionary Nature of The Church. New York: Broadman, 1966.

[4] Brown, Stanley. Evangelism in The Early Church. Grand Rapids, Michigan: Eerdmans, 1963.

[5] Chia, P. S., \& Juanda, J. (2020). Understanding The Relationship Between Faith and Knowledge. Journal

\footnotetext{
${ }^{60}$ Stanley Brown, Evangelism in The Early Church (Grand Rapids, Michigan: Eerdmans, 1963), 48.

${ }^{61}$ H.W Gensichen, Living Missions (Philadelphia: Fortress, 1966), 201.
} 
DIDASKALIA, 3(1), 1-6.

[6] Faot, Agustinus, et al. "Bertahan Sampai Kesudahan Akan Diselamatkan." Journal Kerusso 4.1 (2019): 15-25.

[7] Ferre, Nels F.S. Fear, Duty and Love as Ultimate Motives for Christian Missions. Grand Rapids: Baker Academic, 1948.

[8] Gensichen, H.W. Living Missions. Philadelphia: Fortress, 1966.

[9] Iverson, Iverson. Gereja Sehat dan Bertumbuh. Malang: Gandum Mas, 2003.

[10] Love, Julian. The Missionary Message of The Bible. New York: Macmillan, 1941. [11] Newbigin, Lasslie. The Household of God. New York: Friendship, 1953

[12]Http://christianreformedink.wordpress. com/reformed-theology-

2/pneumatology/doktrin-roh-kudus-dankehidupan-orang-percaya-ind/

[13] Http://bible.org/seriespage/session-9doctrine-sanctification [14]Http://gkjwkm.org/2011/02/membangu n-hidup-dalam-kesatuan-roh-dan-damaisejahtera/

[15] Http://ifgf.org/index.php/in/newstopmenu-82/articles-blogs-sermons/81articles/933-how-to-build-unity [16]Http://katolisitas.org/2008/06/10/bagai mana-caranya-untuk-hidup-kudus/ [17] Http://renungan-

kristen.blogspot.com/2011/03/tak-adaalasan-untuk-tak-hidup-kudus.html [18]Http://sumberkristen.com/Mimbar\%20
Gereja/mimbar\%20gereja\%205/kesatuan\% 20umat\%20Tuhan.htm [19]Http://teologia.mystudylight.com/dilah irkan-kembali.html [20]Http://www.oocities.org/tangkereid/art 2.html Http://www.ronweber.com/Christian/Default.htm [22] Hust, D.S. \& T.J Jones. The Church Begins/ Springfield: Gospel Pub. 1959. [23] Peters, George W. Peters. A Biblical Theology of Missions (Malang: Gandum Mas, 2006), 194-196.

[24] Pink, Athur W. Jaminan Kekal. Lawang: STT Tabernakel, 1996. 